University of Louisville

ThinkIR: The University of Louisville's Institutional Repository

Electronic Theses and Dissertations

1942

\title{
The psychiatric treatment of a group of delinquents.
}

Bernard Finkelstein
University of Louisville

Follow this and additional works at: https://ir.library.louisville.edu/etd

Part of the Psychiatry and Psychology Commons

\section{Recommended Citation}

Finkelstein, Bernard, "The psychiatric treatment of a group of delinquents." (1942). Electronic Theses and Dissertations. Paper 1785.

https://doi.org/10.18297/etd/1785

This Master's Thesis is brought to you for free and open access by ThinkIR: The University of Louisville's Institutional Repository. It has been accepted for inclusion in Electronic Theses and Dissertations by an authorized administrator of ThinkIR: The University of Louisville's Institutional Repository. This title appears here courtesy of the author, who has retained all other copyrights. For more information, please contact thinkir@louisville.edu. 


\title{
UNIVERSITY OF LOUISVIIIE
}

\section{THE PSYCHIATRIC TREATMERT OF A GROUP OF DELINQUENTS}

\author{
A Dissertation \\ Submitted to the Faculty \\ of the Graduate School of the University of Louisville \\ In Partial Fulfillment of the \\ Requirements for the Degree \\ of Haster of Science in Social Administration. \\ Graduate Division of Social Administration
}

By

Bernard Finkelstein

Year

1942 
NAME OF STUDENT: BERNARD FINKELSTEIN

TITIE OF THESIS: THE PSYCHIATRIC TREATMENT OF

A GROUP OF DELINQUENTS

APPROVED BY READING COMMITTEE COMPOSED OF THE FOLIOWING MEMBERS:

NAME OF DIRECTOR:

DATE: MAY 22, 1942 . 
AN ACKONOWLEDGEMENT

The ishes to acknowledge his gratitude to Mr. Gardner F. Cook for his kind assistance, encouragement and personal guidance; to Mr. John J. Cronin for his suggestions and criticisms: to the staff of the Louisville Mental Hygiene Clinic for placing material at my disposal; and especially to Dr. Spafford Ackerly for his help in the analysis of the data. 
THE PSYCHIATRIC TREATMEANT OF A GROUP

OF DELINQUENTS 
TABIE OF CONTEITS

Page

IIST OF TABLIS.................. v

Chapter

I. AN INTRODUCTION TO THE RESEARCH...... I

II. THE CHARACTERISTICS OF THE GROUP..... I6

III. THE TREATMENT PERIOD............ 31

IV. ANALYSIS OF THE RECOVERED AND

UNRECOVERED SUBJECTS............ 45

V. THEORETICAI DISCUSSION........... 64

VI. CONCLUSIONS................... 74

APPENDIX A....................... $7 \eta$

APPENDIX B...................... 86

APPENDIX $c . \ldots \ldots \ldots \ldots \ldots \ldots \ldots \ldots \ldots . \ldots . \ldots . \ldots . \ldots$

BIBLIOGRAPHY..................... 95 


\section{IIST OF TABIES}

Table

Page

1. The Ages of the Delinquents at the Beginning of the Treatment Period......

2. The Intelligence quotients of the Delinquents....................

3. The Age at Wich the Subjects Comitted Their First official Delinquency

4. The Nature and Number of Offenses Wich Were Committed by the Subjects...

5. The Nature and Number of the Dispositions with Which the Subjects Were Charged.......................

6. The Religious Affiliations of the Delinquents................... 27

7. The Number of Siblings in the Family... 28

8. Social Agencies Which Had Contact with The Subjects or Their Families........ 32

9. The Problems as Referred to the clinic. 33

10. The Iength of the Treatment period..... 34

11. The Number of Interviews Between the Delinquent and the Psychiatrist....... 35

12. The Number of Interviews Between the Parents and the Social Worker or Psychiatrist.................. 35

13. Social Relation Within the Family..... 37 
CHAPTISR I

AN INTRODUCTIOÑ TO THE RIRSPARCH 


\section{GLAPTER I}

\section{AN INTRODUCTION TO THE RESEARCH}

The original purpose of this research was to study a controlled sample of twenty-five delinquents who had received psychiatric treatment at the Louisville Mental Hygiene Clinic. The center of focus vas to be on the treatment of the individual and his adjustment to life after treatment had been completed, rather than upon the causes of delinquency.

With this objective as a point of reference. the first step was to determine what kind of a sample was to be selected. A review of the literature showed that a majority of the studies was done with random samples. It was felt that the conclusions which were drawn from these studies were too general to be very useful for specific cases. In order to overcome this limitation, it was decided that a controlled sample should be selected.

1

The studies by $S$ : and E. Glueck, C. I. Burt, W. Healy and N. Hirsch were done with random samples. 
Before any records were taken from the files of the Louisville Mental Hygiene Clinic, it was decided that each case should meet all of the following conditions before it would be selected for study:

1. Each individual must have committed an official delinquency before he was referred to the Mental Hygiene Clinic for treatment.

2. Each individual must have received psychiatric treatment.

3. Each individual should be no younger than eleven nor older than seventeen years of age at the time treatment was begun at the clinic.

4. Each subject must be native born.

5. Both parents of each subject must be native born.

6. Each subject must be within the range of average intelligence, as defined by the Stanford-Binet Intelligence Test.

7. Only white subjects were to be selected.

8. Only males were to be used in this study. These controlling factors were selected so that a more or less homogeneous group, as far as age, place of birth, intelligence, sex and race are concerned, might be obtained.

A list of eighty-eight cases which were referred 
to the Clinic by the Jefferson County Juvenile Court was compiled. With the assistance of a secretary, each one of these cases was pulled from the Clinic's files. The case record was briefly reviewed and if the control conditions were met, the case was laid aside. Only twelve cases were obtained in this way. In order to obtain the thirteen additional cases which were necessary to make up a group of twenty-five subjects, the secretary went through the files and pulled twenty-five more cases which she thought would be satisfactory for this study. This group of thirty-seven cases, in all, was more carefully analyzed and from it, twenty-five cases which met the controlling conditions were selected.

The records were analyzed in detail. The information which was obtained about each case was recorded on an individual schedule. The juvenile court records were utilized to obtain all the information concerning the official delinquencies and the dispositions of the charges. A follow-up visit was made to the homes of those individuals who could be located.

1 Infra. p. 91. 
It was decided, then, to classify these delinquent individuals according to the classification system which was devised by William Healy in the study, "New Iight on Delinquency and Its Treatment". The decision was made in order to see if a clearer picture of the general nature of the group might be obtained. The cases were classified by the psychiatrists who had treated the individuals. The results of this procedure were that twenty cases fell into Healy's Group I, one case into Healy's Group II and four cases into Group III. In the study by Healy, twenty-six of the one hundred and forty-three delinquents fell into Group I. We, therefore, has a group of delinquents which was relatively comparable in size to Healy's Group I.

The major purpose of this thesis is to make a detailed analysis and follow-up of a group of twenty delinquents who were classified as belonging to Healy's Group I. Comparisons will be made between the delinquents of this stuay and those of the Healy otudy to see if there are any differences between the two investigations. As far as we know, there has been no

1

W. Healy and A. Bronner, New Light on Delinquenct and Its Treatment (New Haven: Yale University Press, 1936)

2

Infra. pp. $8 \mathrm{ff}$. 
study which has checked the findings of the Healy study in relation to Group I. The Healy study itself did not make a very detailed analysis of Group I. It may be possible that more can be learned about these individuals as a result of making a detailed analysis. The study will show, in part, how effective the treatment of those who fall into Healy's Group I has been at the Mental Hygiene clinic. The Clinic had no follow-up data on these cases at the time this study was begun. Another aim was to see what differences existed between those who had recovered and those who had not, if sufficient cases were found to make the comparison legitimate. It was not possible for Healy to compare the recovered individuals of Group I with the unrecovered individuals of that group because there was not a sufficient number of individuals who recovered. An attempt is made, in this study, to formulate an adequate treatment program for delinquents of this type.

Before any analysis of the data is made, it seems best to aiscuss the study, "New Light on Delinquency and Its Treatment". In that stuay, the delinquents were the experimental group and their non-aelinquent siblings were the control group. The study was an attempt to acheive some understanding of the nature and causes of delinquent activities. According to the authors, no particular prejuoices or theories were adhered to. In 
the introduction to the study, they said: "The very essence of this research lies in the fact that no theoretical paths have been pursued as related to causation or treatment, the main aim is to discover the forces creating delinquent trends." ${ }^{l}$

In this study of Healy's, $92 \%$ of the delinquents were said to display major emotional disturbances. Most frequently found were feelings of inadequacy or inferiority. These were persistently present in almost onehalf of the group of 143 delinquents. Slightly fewer cases were aisturbed by feelings of being rejected or insecurity in affectional relationships. About onethird experienced feelings of being thwarted, onethird were upset by familiy conflicts and disharmonies and one-third were emotionally disturbed because of rivalry with their siblings.

The treatment plan of the study was similar to 1 that of a modern child guidance clinic. The clinical unit was not located in the juvenile court buildings. Attempts at therapy were continued even if the prognosis were poor. After treatment had been completed, the 143 delinquents were divided into three groups, based upon prognostic criteria.

Healy and Bronner, op. cit., p. 22.

2 Infra. p. 87 . 
Group I consisted of delinquents who could not be considered hopeful for treatment, even under ordinarily good conditions of family and community life. They were the markedly neurotic or abnormal personalities, the unstable personalities, those suffering from severe mental conflicts and the mental defectives who had already established delinquent tendencies. Of the 143 delinquents, 26 (18\%) were classified as belonging to this group.

"For the 26 cases in Group I, it appears that only one individual at the end of the treatment period had overcome his delinquent tendencies." ${ }^{1}$ In other words, the treatment which these subjects had received was not effective in halting their delinquent activities.

Group II consisted of all those cases in which social pathology, particularly as involving human relationships within or outside the family group, appeared to weigh so heavily against the possibility of successful treatment of the delinquent in his family environment that the given situation seemed hopeless. There were 50 cases in this group. About $80 \%$ lived in high delinquency areas. "The final report is that 
19 cases (38\%) of Group II have not been delinquent during a period of two or more years."

Group III ( 67 cases) consisted of cases in which after investigation or earliest attempts at treatment, the outcome seemed hopeful. They were inàividuals whose personality or internal difficulties did not show extreme deviations and they came from environments where the social conditions did not Ëive evidence of greatly weighing against chances of successful treatment. "During a follow-up period of two or more years, 48 cases (72\%) of Group III have not been delinquent." ${ }^{2}$

The grouping of delinquents according to potential success of treatment, based upon a study of the personality make-up and environmental conditions of the subjects is one of the most valuable contributions of the study. This classificatory system has made invalid the study of random samples of delinquents insofar as preaicting the outcome of treatment is concerned. S. and

1.

Ibià., p. 168.

2

Ibid., p. 170. 
E. Glueck have recently completed a fifteen year study of one thousand delinquents. According to the authors:

of the 806 youths who were on straight probation at one time or another during their delinquent careers, and about whose behavior on probation sufficient information could be secured to determine success or failure, $164(20.3 \%)$ always behaved well, 467 (57.9\%) always failed and 175 (21.8\%) sometines succeeded and sometimes failed.

The study by Healy and Bronner shows that the success or falure cannot be determined from a random sample but that the more valid method is to classify the delinquents. Once this has been done, treatment can be successful in as few as $4 \%$ of the cases or as high as $72 \%$ of the cases. As a result of classification, a much more specific statement can be made.

The way in which the delinquents of the Healy study were obtained is important to the present inves-

1

S. and E. Glueck, Juvenile Delinquents GrownUp. (The Commonwealth Pund: Oxford University Press, 1940), p. 330 . 


\section{1}

tigation. In that study, the delinquents were taken from the jurenile courts as the case load of the clinical unit permitted. All were to be able to speak English. No feeble-minded were to be accepted for treatment. None were to be ruled out because the co-operation of parent or child seemed difficult to win.

Another point of importance is the classification of the delinquents into the three groups. How, when and by whom were they classified? The definitions of the three groups were formulated. The delinquents who were studied were classified after the clinical units had been closed. Treatment had been terminated. The psychiatrists who had treated the cases made the classifications.

We shall discuss Group I at greater length because of its relationship to this stuay. It is not that we consider Groups II and III unimportant but a more detailed discussion of them would not be relevant to this study.

Group I consisted of those individuals for whom treatment seemed least hopeful. The major point is that it was the personality structure and integration of these subjects rather than the social or economic conditions which placed them in Group I. This group included the 
unstable personalities, the psychopaths, the neurotics, the brain injury cases, the homosexuals and the postencephalitics. In other words, it was the pathological nature of the delinquents' personalities which placed them in this category. There were twenty-six delinquents who fell into Group I. Only one ceased his deIinquent activities at the end of the treatment period.

The Healy study presents massed data for all of the delinquents who were studied. There is no breakdown of the data according to the group classifications. In this study, we shall present a detailed analysis of twenty individuals who belong to Healy's Group I.

The question may arise as to whether or not we can validly classify the delinquents of this study and make any comparisons with the Healy study. The facts are as follows:

The Nedical Director of the Louisville Mental Hygiene Clinic had been the psychiatrist at one of the clinical units of the Healy study. He, therefore, was familiar with the classification system. The same psychiatric approach was used in both studies. Comparison would not be valid if a classical analytical approach were used in one situation and a more direct psychiatric approach in the other. There is no conflict between the two studies insofar as the psychiatric methodology is concerned. 
The method of classification which was used in this study seems to be the only valid one which can be utilized. The psychiatrists who treated the individuals classified them. According to the National Committee for Mental Hygiene, evaluation of persons who have received psychiatric treatment is difficult, if not impossible, unless the psychiatrist who has treated the individual makes the evaluation. It was indeed fortunate that the psychiatrists who had treated the individuals of this study could be reached. One of the most difficult tasks in research is to be able to contact the psychiatrist who had worked on a case and have him evaluate them for classification or diagnosis, especially if the case had been closed for a number of years. Treatment was begun as early as 1933 in some cases and as late as 1939 in others.

The psychiatrists went over the twenty-five case records and classified them, using Healy's definitions of Groups I, II and III as the basis for classification. The classification was made before the reports of the follow-up study were submitted. Of the twenty-five cases, twenty fell into Group $I$, one into Group II and four into Group III. We shall study only Group I. 
In order to attempt an evaluation of any treatment program, criteria of successful treatment must be formulated. Successful treatment will be determined on the basis of whether or not these criteria are met. In the field of juvenile delinquency, the first thing we look for is whether or not the delinquent activities have ceased. This, obviously, is one goal of a treatment program, but it should not be the only one. Another factor to consider is the welfare of the individual and his adjustment to life. Therefore, if the indiviaual is making a satisfactory adjustment in life at the present time, treatment will be considered successful, in spite of the fact that he may have committed some delinquent act after treatment had been completed. Treatment will not be considered successful if the individual is not socially productive, for example, continuously unemployed. There may be some objection to this last statement for it might be said that the individual was a victim of mass unemployment. This may be valid but we shall attempt to find out whether or not he has atterpted to look for a position, or, whether or not he has been erratic in his work. If the individual is in a reformatory, jail or prison, treatment will be considered unsuccessful. These criteria are very similar to the ones utilized by Healy, except that Healy considered treatment unsuccessful if the subject committed any delinquent act after treatment was completed. 
The court records will be used to determine whether or not delinquent or criminal activities have continued or ceased; the follow-up visit will be used as a basis for determining the adjustment that the subjects are making to-day. We realize that it is difficult to determine whether or not the second criterion has been met, but we shall make the attempt. 
CHAPTER 2

THE CHARACTERISTICS OF THE GROUP 
CHAPTER 2

THE CHARACTERISTICS OF THE GROUP

This section shall be deroted to an analysis of the data which describes the characteristics of the group.

TABIST 1

THE AGES OF THE DELINQUENTS AT THE BEGINNING OF THE TREATMENT PERIOD

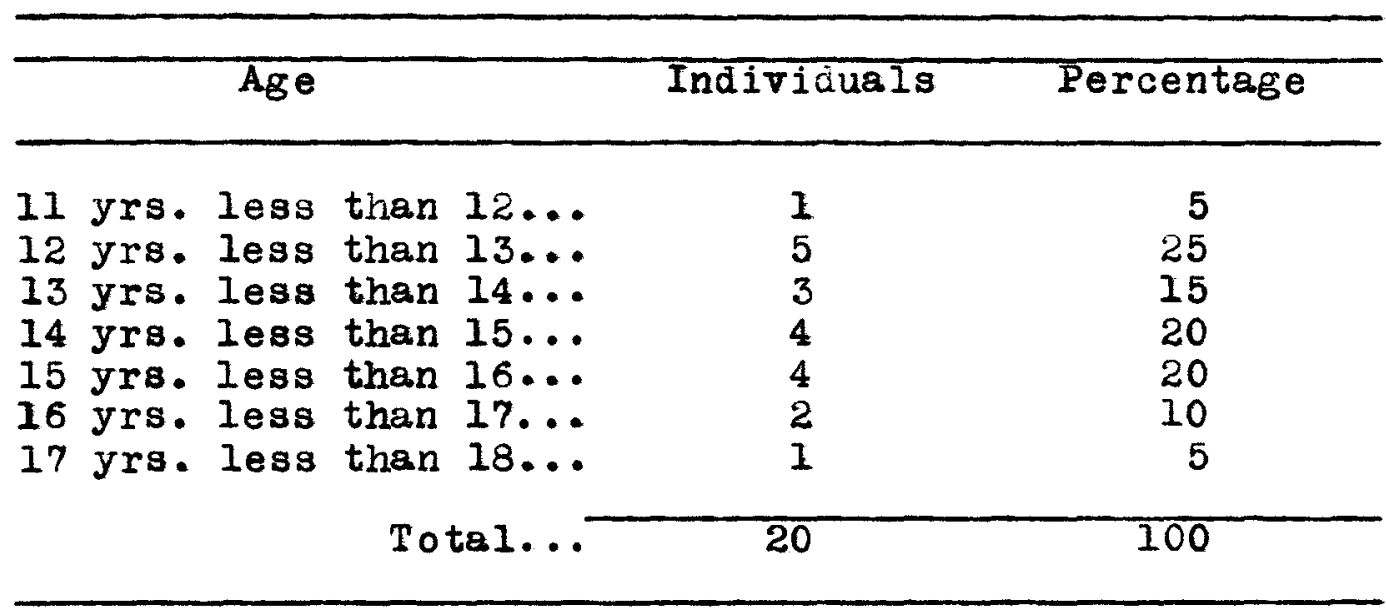

The age range of the delinquents at the beginning of the treatment period was from 11 years and 0 months to 17 years and 0 months. The mean age of the group was 13 years and 10 months at the beginning of the treatment period. This means that all were in the adolescent stage of development (if it is accepted that the adolescent period begins somewhere about the age of 11 or 12 ), and eliminates the pre-adolescent delinquent. 
We are not attempting to set any norm for the adolescent period; we are merely using 11 years of age as a base. In using inaividuals of the same age range, it may be possible to obtain a clearer picture of the group.

\section{THE STATE OF BIRIH OF THE DELINQUENTS}

of the 20 subjects, 16 or $80 \%$ were born in Kentucky, 2 were born in Illinois, 1 in Indiana and 1 in Arkansas. According to the information which was obtained from the case records, all had lived in the city of Louisville for the greater part of their lives.

THE STATE OF BIRTH OF THE PARENTS

If we consider the fathers, 11 or $55 \%$ were born in Kentucky, 3 were born in neighboring Indiana, and I in each of the following states: Illinois, Colorado, Arkansas, New York, Virginia and Tennessee. Of the 20 mothers, 12 or $60 \%$ were born in Kentucky, 2 were born in Indiana and 1 in Illinois, Colorado, Alabama, Louisiana, Arkansas and Virginia.

The delinquents and their parents were all native born. The control of this factor eliminates the question of culture conflict, as a result of being foreign born or having foreign born parents, as a cause 
of the delinquent acts of this group. S. and E. Glueck found that $80 \%$ of the delinquents of their study were native born and that $80 \%$ of the parents were foreign born. They concluded that the differences between the standards and mores of the foreign born parent and the native born child caused conflict between the two. As a result of this conflict situation, the child engaged in delinquent activities. There was no conflict between the delinquents of this study and their parents with cultural differences being the basis for the conflict. Whatever conflict there was between parent and child had to to have a different basis for its being.

\section{TABLE 2}

THE INTELLIGENCE QUOTIHNTS OF THE DELINQUENTS

$$
\text { Individuals }
$$

Intelligence Quotients Number Percentage

\begin{tabular}{|c|c|c|}
\hline $\begin{array}{r}84-91 \ldots \ldots \ldots \ldots \ldots \ldots \\
92-108 \ldots \ldots \ldots \ldots \ldots \ldots \ldots \\
109-116 \ldots \ldots \ldots \ldots \ldots \ldots \\
117-124 \ldots \ldots \ldots \ldots \ldots \ldots \\
125-132 \ldots \ldots \ldots \ldots \ldots \ldots \ldots \\
133-149 \ldots \ldots \ldots \ldots \ldots \ldots\end{array}$ & $\begin{array}{r}3 \\
11 \\
4 \\
1 \\
0 \\
1\end{array}$ & $\begin{array}{r}15 \\
55 \\
20 \\
5 \\
0 \\
5\end{array}$ \\
\hline 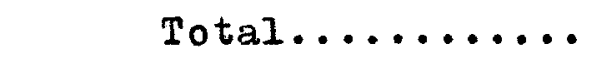 & 20 & 100 \\
\hline
\end{tabular}

The range of the intelligence quotients, as obtained from the results of the Stanford-Binet Intelli- 
gence test, for this group, is from 84-137. The average I. Q. is 97.5 . According to the verbal classification, 1 is of Superior intelligence, 1 is Bright, 4 are of High Average intelligence, 11 are of Average intelligence and 3 are of Low Average intelligence. All the subjects of this study are within or above the range of average intelligence as defined by this test.

One of the most misunderstood concepts is that of intelligence in relation to delinquency and crime. "Among specialists in the problems of delinquency, heated arguments break out when mental or intellectual deficiency is put forth as a contributing cause." Low intelligence cannot be considered a causative factor of the delinquencies which were committed by the members of this group.

\section{THE SEX FACTOR}

The delinquents studied are males. This selection was made to control the factor of sex differences. We believe that there is much difference between male and female delinquent activities. In our society, cultural mores, codes and standards are different for the male and the female. This is true in the

1

C. Bird, Social Psychology (N. Y. \& London: Century series, 1940), p. 472 . 
field of delinquency and crime as well. An analysis of the types and frequency of the offenses committed by maleo and females will lend support to this statement.

W. Healy found that $60 \%$ of the offenses committed by females were of a sexual nature and $32 \%$ were stealing offenses; $5 \%$ of the offenses committed by males were of a sexual nature and $66 \%$ were stealing. ${ }^{l}$ c. Burt found that $36 \%$ of the female of fenses were sexual and $43 \%$ were stealing; $14 \%$ of the male offenses were sexual and $79 \%$ were stealing. 2 S. \& $\mathbb{E}$. Glueck, in their latest study, found that . $3 \%$ of the offenses committed by males were of a sexual nature and that $63 \%$ were stealing. The differences in the statistics are probably due to the definitions of the offenses, the areas in which the stuaies were done and the techniques used to obtain the information. However, there is evidence that much of the female delinquencies are of a sexual nature, whereas, most of the male offenses are of a stealing nature.

1

W. Healy, The Individual Delinquent(Boston:

Little, Brown, anã Co., 1916), p. 14.

2

C. Burt, The Young Delinquent (New York: Appleton, 1925), p. 103 .

3

Glueck \& Glueck, op. cit., p. 16 . 
It is to eliminate the question of sex differences and the possibility of different motivating factors that all males were selected in this study.

\section{RACE}

Only white boys were studied. Statistics show that the proportion of colored delinquents in relation to all delinquents is greater than the proportion of colored people in relation to the total population. In addition, there may be different motivating factors between the white and colored delinquents. To avoid these differences, only white boys have been selected for study.

\section{SOCIO-ECONOMIC STATUS OF THE FAMIIIES}

The case recoras did not contain the salaries or incomes of all cases but most of the families about whose income there was some data were of low economic status. Partial data shows that the average income was about $\$ 14.55$ per week, with a salary range of $\$ 6-40$ per week. Rentals averaged about $\$ 15.00$ per month. This data is not complete enough to allow us to draw any conclusions about the relation between low socioeconomic status and delinquent activities. 
TABIE 3

THE AGE AT WHICH THE SUBJECTS COMMITTED THEIR FIRST OFFICIAL DELINQUEITCY

\begin{tabular}{lccc}
\hline & & Individuals & Percentage \\
\hline Age & & 6 & 30 \\
11 yrs. less than $12 \ldots \ldots$ & 5 & 25 \\
12 yrs. less than $13 \ldots \ldots$ & 2 & 10 \\
13 yrs. Iess than $14 \ldots \ldots$ & 3 & 15 \\
14 yrs. less than $15 \ldots \ldots$ & 4 & 20 \\
15 yrs. less than $16 \ldots \ldots$ & 20 & 100 \\
\hline
\end{tabular}

The average age at which the subjects committed their first official delinquency was 13 years and 1 month. None committed any delinquent act before the age of eleven, as determined by a review of the juvenile court records.

THE NATURE AND NUMBER OF THE OFWENSES MHICH WERE COINITTED BY THE SUBJECTS

An analysis of Table 4 shows that stealing was the offense most frequently committed by the subjects. There were 58 stealing offenses which accounted for $72 \%$ of the total number of delinquencies which were committed by these individuals. Fifteen of the twenty were charged with stealing. A further break-down of the stealing offenses shows that eleven broke into stores 


\section{TABLE 4}

THE NATURE AND NUMBER OF OFFENSES WHICH WERE COMMITTED BY THE SUBJECTS

\section{Offenses}

Stealing............. 58

Running away............ 7

Disorderly Conduct......... 3

Rape.................. 2

Possession of stolen goods.... 2

Armed robbery.............. 2

Wandering about............ 1

Assault and Battery........... 1

Truancy ................ I

Riding in stolen car........ I

Hopping on street car........ 1

Passing counterfeit money.... 1

72

9

4

3

3

3

1

1

1

1

1

1

Total.

$\therefore 80$

100

and stole articles from them, seven stole automobiles and seven stole money or jewelry. Store breaking and stealing from them were the most frequently committed offenses. Stealing can be considered a direct, though socially unacceptable, way of obtaining what is desired.

Running away accounted for 7 of the offenses. Seven individuals were charged with this offense. If we consider running away as an escape mechanism, then, seven of the subjects tried to "run away" from their problems, at one time or another during their delinquent careers. 
The other offenses occurred too infrequently to attempt any analysis of them. However, a few words can be said about the nature of delinquent offenses. Some offenses are more overt than others, as far as their nature is concerned. For example, stealing or disorderly conduct requires much more direct activity than does truancy or wandering about. Howerer, there is some degree of overtness to all delinquent activities, otherwise the individuals would never be brought to a juvenile court. This is an important factor in the understanding of delinquent individuals. Whatever the means may be, socially acceptable or not, the delinquent is doing something about his situation.

\section{TABI 5}

THE NATURE AND NUMBER OF THE DISPOSITIONS OF THE OFFENSES WITH WHICH THE SUBJECTS WERE CHARGED

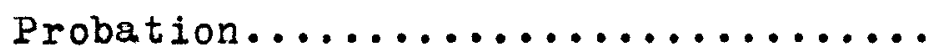

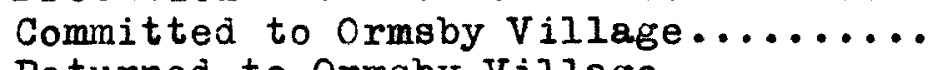
Returned to Ormsby Village............ Committed to Federal Reformatory..... Committed to Kentucky House of Reform Committed to the Psycho-pathic Ward..

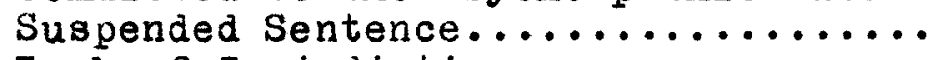
Lack of Jurisdiction.

21

13

17

4

2

1

1

1
34

22

28

7

3

2

2

2 
Probation was used most frequently as a means of disposing of the charges ( $34 \%$ of the total dispositions). Fourteen of the twenty subjects were on probation at some time or other during their delinquent careers.

Commitment to the Louisville and Jefferson County Children's Home (Ormsby Village), a correctional institution, was used as a means of disposing of 13 of the charges. Thirteen of the subjects were sent to that institution at one time or another during their delinquent careers. Before an individual was committed to Ormsby Village, he usually had committed more than one offense, or, his first official offense was of such a serious nature that he was cormitted to that institution. Three of the delinquents were wards of the institution while they were receiving treatment at the Mental Hygiene Clinic. They were not in the institution at the time but were on parole to their parents and were living in the community.

Return to Ormsby Village for violation of parole accounted for 17 or $28 \%$ of the dispositions. Ten of the thirteen boys who were committed to that institution had to be returned there on one or more occasions. 
Four of the boys were committed to a federal reformatory for violation of the National Motor Vehicle Act.

Two were committed to the Kentucky House of Reform at Greendale. This institution is for the more serious of fenders.

One was committed to the Male Psycho-pathic Ward of the Louisville General Hospital for observation because of a rape charge.

In one instance, a suspended sentence was the decision and, in another (the rape charge), the juvenile court lacked jurisdiction.

TABLE 6

THE RELIGIOUS AFFILIATIONS OF THE DELINQUENTS

\begin{tabular}{|c|c|c|}
\hline Religion & Individuals & Percentage \\
\hline 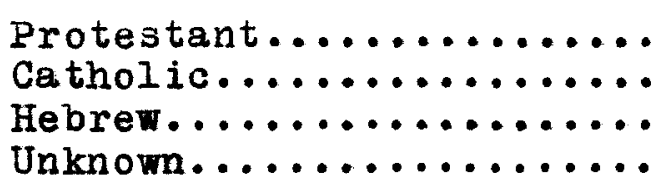 & $\begin{array}{r}15 \\
2 \\
1 \\
2\end{array}$ & $\begin{array}{r}75 \\
10 \\
5 \\
10\end{array}$ \\
\hline Total...... & 20 & $\overline{100}$ \\
\hline
\end{tabular}


There is a slightly higher proportion of Protestants in this group than is true of the population of the city of Louisville.

TABIE 7

THE NUMBER OF SIBLINGS IN THE FAMILY

Number of Siblings Number of Families

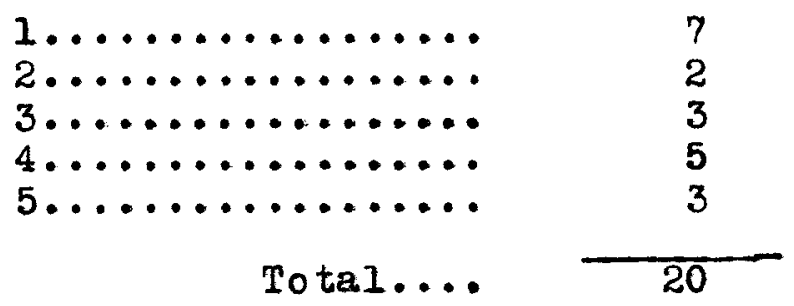

The average size of the family, excluding the parents, was 2.8 chilaren per family unit. Seven of the subjects had no other sibling. The delinquents of this group tended to be the oldest or youngest child in the family.

\section{THE HOMES}

The homes of fourteen of the delinquents were not broken; the homes of six were broken. In two cases, the home was broken by the deathe of the father, one home was broken by the death of the mother and three were broken because of separation of the parents. 
It is difficult to determine what effect living in a broken home has upon the individual. First of all, it is necessary to determine whether the home was broken by death, illness, desertion, separation, imprisonment or divorce. Presumably, a home broken by the death of a parent would be more wholesome from the standpoint of the child's socialization than one broken by desertion or divorce. It is only through examination of the specific situation that the effects of living in a broken home may be determined.

In relation to this group, the following are some of the effects upon the child, as a result of Iiving in a home broken by:

Separation.
Case 1) The mother had hated the father and carried these feelings over to the son.

Case 2) The mother was out of the home most of the day. The boy received little affection.

Case 3) The boy lived a mobile life. He had no affectional ties or adequate supervision. 
Death of the father.

Case 1) The mother centered all her hopes on the boy. He could not meet her standards with the result that he had intense inferiority feelings.

Case 2) The mother was unstable. There was an intense need for a father-substitute.

Death of the mother.

Case 1) The father became a dope addict and was not interested in the boy. The boy was in an intense conflict situation.

These results show that the homes which were broken were not very wholesome in terms of affectional relationships. We are not saying that every home which is broken will be affected in the same ways. This is a report of what was true of the subjects of this study who lived in broken homes. 
CHAPTER 3

THE TREATMENT PERIOD 
This section shall be devoted to a presentation of the treatment program which the subjects underwent at the Louisville Hental Hygiene Clinic

TABIE 8

SOCIAL AGENCIES WHICH HAD CONTACT WITH THE SUBJECTS OR THEIR FAMILIFS

Agency

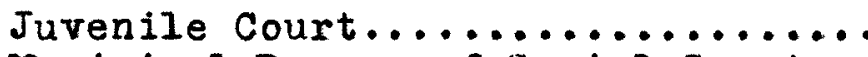
Municipal Bureau of Social Service.

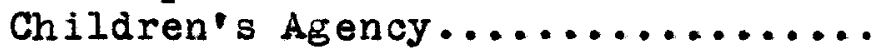

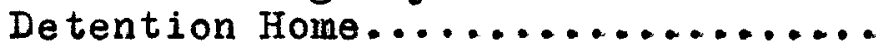

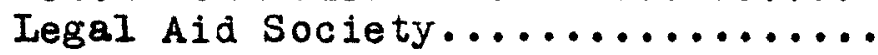
Family Service organization........ Children's Free Hospital........... Board of Tuberculosis Hospital..... Public Health Nurses Association...

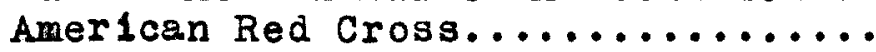
Traveler's Aid...................

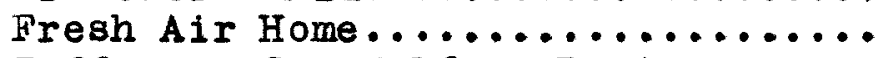
Jefferson Co. Welfare Dept......... Male Psycho-pathic Ward, General

Hospital...

Total.....

\section{Number of Individuals or Families Served}

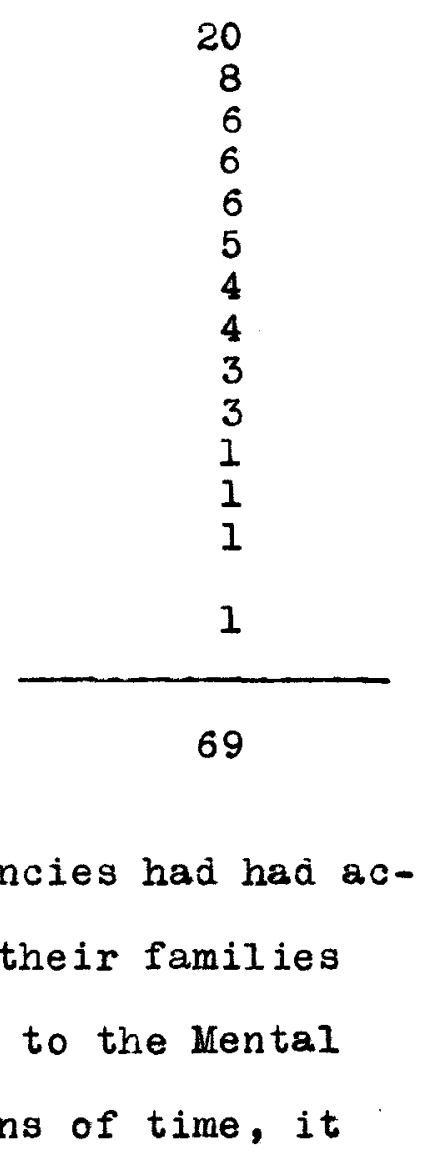

Fourteen different social agencies had had active contact with the delinquents or their families before the subjects had been referred to the Mental Hygiene Clinic. Because of limitations of time, it 
has not been possible for us to analyze the case records of the other social agencies. It is important to state, however, that about half of the delinquents were referred to the Clinic by social agencies other than the Jurenile Court. Whenever possible, other social agencies were included in the treatment program. Six of the cases were referred to the liental Hygiene Clinic immediately after they had committed their first official delinquency, eight were referred to the Clinic at least one year after their first official delinquency and six were referred to the clinic from two to five years after their first official delinquency.

\section{TABIE 9}

THE PROBLEMS AS REFTRRED TO THE CLINIC

$$
\text { Problem Frequency of Occurrence }
$$

Stealing.............

Personality problem......

Running away............

Uncontrollable..........

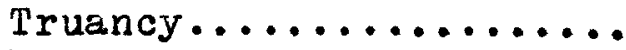

Hy peract ive...........

Nervous and irritable....

Lying and lack of morals.

Bad companions...........

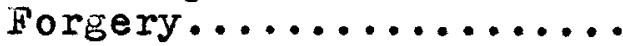

School problem..........

Total
10

9

7

4

4

3

3

3

2

1

1

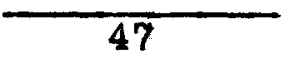

An analysis of this table shows that most of 
the problems deal with personality factors rather than with the delinquent activities as such. Nine of the subjects were referred as " personality problems". If the relatively untrained personnel who referred these cases recognize the personality deviations of these subjects, it is not illogical to assume that these deviations would appear greater to the trained personnel of the clinic.

TABLE 10

THE IENGTH OF THE TREATMENT PERIOD

Number of Years

1yr. less th
2 yrs. less t
3 yrs. less th
4 yrs. less th
5 yrs. less th

than 1
than 2
than 3
than 4
than 5
than 6

Number of Individuals

11

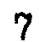

1

0

0

1

Total..........

20

The average length of the treatment period was

1 year and 3 months, with a range of 2 months to $5 \frac{1}{2}$ years. In Healy's study, the individuals received treatment for an average of 1 year and 2 months with a range of 4 months to 2 years and 9 months. There is little difference between the two groups as far as the length of the treatment program is concerned. 
TABLET 11

THE NUMBER OF INTERV IFUS BETWEAN THE DELINQUENT AND THE PSYCHIATRIST

Number of Interviews

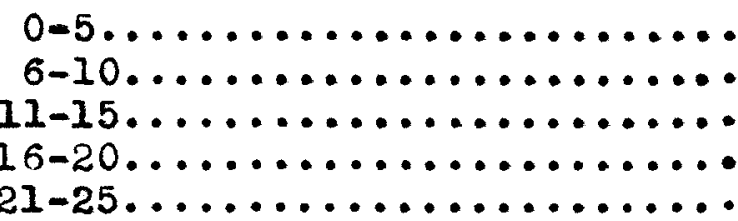

Total....
Individuals

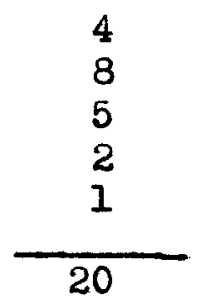

There was an average of 9.3 interviews between the delinquent and the psychiatrist. In terms of time, the delinquents saw the psychiatrist about twice a month.

TABLF 12

THF NUMBER OF INTERVIEWS BETWEEN THE PARENTS AND THE SOCIAL WORKERS OR PSYCHIATRIST

Number of Interviews

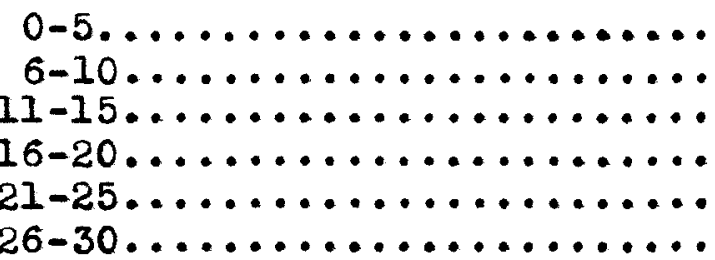

Total....
Individuals

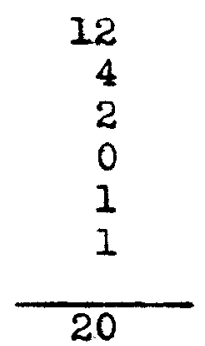

Although the average number of interviews between the parents and social worker or psychiatrist was 5.9 per case, 12 of the parents had less than 5 interviews. Iittle work was done with the parents, even 
though it is the clinic's policy to include the parent in the treatment program. The major reason why there was so little contact with the parents was the unwillingness of these parents to co-operate with the staff. The Clinic could not force the parents to come in. The work was mainly with the delinquent.

There was an average of three conferences per case. The conferences were held to evaluate the work that had been done and to make plans for future treatment. Whenever it was possible, representatives of other social agencies, who had active contact with the case, were invited to the meetings.

The total number of interviews per case includes the interviews between the delinquent and the psychiatrist, the interviews with the parents and the number of conferences which were held. The average number of interviews per case was 18.0. The total number of interviews for all cases was 360 .

RAPPORT BETWEEN THE PSYCHIATRIST AND THE DEL INQUENTS

The word 'rapport' is used, in this study, simply as the relationship that exists between two people. There will be an adjective to describe the kind or nature of the relationship. We have used the psychiatriat's description of the relationship and not 
our own evaluation of it.

The results show that the psychiatrist felt there was poor rapport in ten cases, fairly good rapport in five cases, rapport was not fully established in one case and no evaluation was made in four cases because the psychiatrist was not sure of the nature of the relationship.

TABIE 13

SOCIAI RBELATIONS WITHIN THE FAMILY

Social Relations

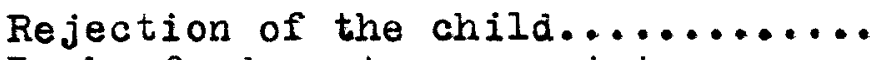

Lack of adequate supervision.......

Poor marital relations.............

Over-protection of the child.......

Nagging or being over-critical.....

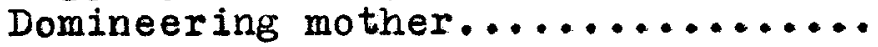

Good, stable home...............
Number of Cases

8

8

8

8

8

3

2

The definitions of the social relationships which are set forth in this study are those which are usually accepted in child guidance clinics.

Rejection of the child usually means that there was a desire by one or both of the parents to be rid of the child. The child has the feeling that he is not wanted. Symptoms of rejection may be varied, such as, nagging the child, ignoring the child, or, over-protection because of guilt feelings on the 
parent's part.

Iack of adequate supervision may mean that there was no supervision or that supervision was lax, erratic or too strict. In other words, the discipline was not in keeping with the situation.

Poor marital relations may mean difficulties between the parents because of poor sexual adjustment or poor social adjustment to each other.

Over-protection of the child can mean that the child is defended, excessively, by the parents from Iffe situations. Spoiling, constant attention, being over-zealous for the child and restricting the child's activities are ways by which a child can be over-protected.

Nagging or being over-critical may mean that one or both of the parents made constant demands upon the subject or criticized his activities unduly.

A domineering mother may mean that the mother was rather strict, "wore the pants" in the household, directed and restricted the child's activities.

A good, stable home was one in which the relations between the family members were warm, affectionate 
and binding.

Review of this table shows that in only two of the twenty homes were the social relationships thought to be good. In the other eighteen cases, there was social pathology in one form or another.

\section{MEDICAL FINDINGS}

The term, medical findings, includes the results of the physical and neurological examinations which each subject received. In fifteen of the twenty cases, the findings were essentially negative. That is, in these fifteen cases, the phyoical and neurological conditions of the subjects were generally good. There were five cases in which a head injury was sustained and the individuals were unconscious as a result of the injury. The neurological findings were negative in four of these cases but this does not rule out the possibility of some brain damage. In the other case, although nothing definite could be found, there were indications of some neurological disturbance. One gave a history of encephalitis lethargica. Two had a positive Kahn test but both received treatment and were 
non-infectious. One receiveà gland therapy after a diagnosis of glandular deficiency was made. An airencephalagram was used in the diagnosis of the case which was felt to have a possible frontal lobe atrophy. The encephalagram of the brain was abnormal, but it was impossible to determine the specific disabilities which resulted from the brain abnormality.

The results show that fifteen of the twenty were in good physical and neurological condition as far as could be determined from the examinations. Five experienced head injuries and, al though the neurological findings were essentially negative, we cannot rule out the possibility that the head injury may have had some relationship to the personality integration of these subjects.

\section{THE NATURE OF THE TREATMENT}

The treatment of the delinquent was individualIy determined. However, there were some principles or methodologies which were used in all cases which aemanded their use. We shall attempt to enumerate some of the principles which the psychiatrists followed. 
The psychiatrist accepted the child. He tried to understand the patient as he was and not as he "should be". No child was blamed for his delinquent activities. There was an attempt to get the child to accept the psychiatrist, as well as the psychiatrist's accepting the child.

Meeting reality or facing the facts of the situation was utilized in all cases. Although the child as not blamed for committing a delinquent act, an attempt was made to have him understand that he was a delinquent, that delinquency was a legal matter and that he was responsible to society for his behavior.

There was an attempt to "talk through" the situation in order to get the child to talk about his feelings, his difficulties and his problems as they were related to the situation. This was an attempt to solve some of the problems by interpretation, suggestions and a release of internal tension.

The giving of responsibility and the use of self-determination of action was an attempt to establish feelings of security in the individual. The subject wasn't forced to do or accept anything which the psychiatrist suggested. The child was permitted to 
decide for himself what he wanted to do, whenever this was possible. The giving of responsibility to an overprotected child was an attempt to develop feelings of independence and security.

Praising a child's behavior or performance, when praise was justified, was used to raise feelings of status and served as a means of recognition of the child's efforts.

In those cases in which the child was rejected by the parents, an attempt was made to put the parentchild relationship on a firmer basis.

In those cases in which discipline was inadequate, an attempt was made to have the parents understand the nature and purpose of discipline and to be consistent and just in its use.

For those children who were the "Ione wolf" type, an attempt was made to socialize them by getting them to join youth clubs and organizations.

BEHAVIOR OF THE DEIINQUENTS DURING THE TREATMENT PERIOD

Seventeen of the twenty did not commit any official delinquencies during the time that they were 
under treatment at the Mental Hygiene clinic. This is a most important point if we keep in mind the nature of the personalitieg of this group. According to William Healy, this group is the one which seems least hopeful for treatment. Yet, we find, in this study, that seventeen did not commit any offenses during the treatment period, as determined by the court records. It is possible that unofficial delinquencies were committed but we have no record of them, so that we cannot say anything about that possibility. Three of the group committed ten official delinquencies. Hight of the offenses were stealing, one was charged with running away and the other was charged with possession of stolen goods.

\section{CHANGES IN THE DELINQUENT'S ATTITUDES}

The results are that the psychiatrist who worked with the cases felt there was some improvement in attitude in three cases, little improvement in seven cases and no improvernent in ten cases. Some of the factors relating to change or lack of change in attitude were:

In those cases in which there was some improvement, the boy developed greater insight into the nature of his problems, in another case, a better relationsinip was established with the father and, in the third case, there was some resolution of the conflicts which the subject faced. 
In the seven cases in which there was little improvement, six of the mothers were unco-operative, three of the children were unresponsive to emotional appeal, that is, they were "cold" or apathetic to emotional stimulation. Two of the children were on the defensive, one felt restricted and one felt that Clinic treatment was a form of punishment.

In the ten cases in which there was no improvement, four of the children were felt to be developing psychopathic personalities, two were absolutely apathetic to emotional appeal, two had paranoid attitudes of suspicion and resentment, one was a pathologically indifferent neurotic and one was subject to manic flights.

\section{CHANGES IN THE PARENTS' ATTITUDES}

In fifteen cases, there was no improvement in the parents' attitudes towards the child. There was little improvement in two cases, some improvement in one case and no evaluation was made in the other two cases. Work with the parents was generally unsuccessful because of the inability to obtain the parents. co-operation. 
CHAPTER 4

ANALYSIS OF THE RECOVERED AND UNRECOVERED SUBJECTS 


\section{CHAPTER 4}

\section{ANALYSIS OF THE RECOVERED AND UNRRCOVERED SUBJECTS}

The final report on the subjects of this study, insofar as delinquent activities are concerned, is that delinquent activities have continued in fourteen cases after treatment had been completed and that delinquent activities have ceased in six cases. Healy found that only one of Group I discontinued his delinquent activities at the end of the treatment period. Our results show that $70 \%$ continued their delinquent careers and $30 \%$ did not. The important contribution is not the percentage, as such, but the fact that it enables us to make a comparison between the six who recovered and the fourteen who did not.

It was not possible for Healy to make any such comparative analysis between his recovered and unrecovered Group I subjects because he had an insufficient number who recovered. We shall make a detailed analysis and attempt to find out if there are any significant differences between those who recovered and those who did not.

The first part of the analysia will use the criterion of whether or not delinquent activities have 
ceased after treatment had been completed. The second part of the analysis will be a discussion of the followup visit and a presentation of the status of the subjects as of 1942 .

\section{THE HOMES}

Recovered Unrecovered

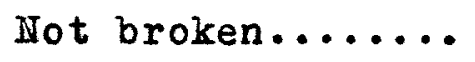

4

10

Broken

2

4

Toted...
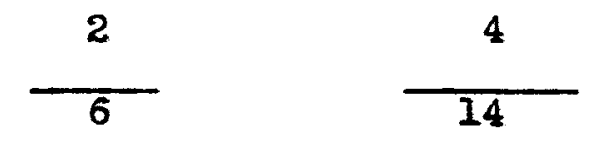

On a comparative basis, there is little difference between the two groups. Of the recovered group, $33 \%$ of the homes were broken and $67 \%$ were not; $28 \%$ of the unrecovered group's homes were broken and $72 \%$ were not.

\section{REI IG ION}

\section{Recovered Unrecovered}

Protestant........

Catholic.........

Hebrew...........

Unknown.

Total...
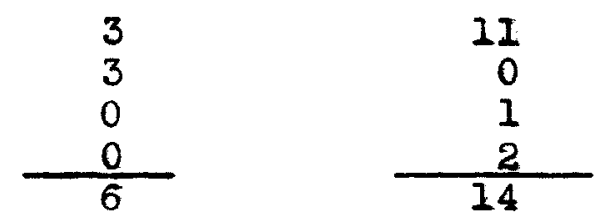

The group is too small to draw any conclusions about the effectiveness of religious training in causing an individual to cease a delinquent career. SecondIy, the religious beliefs and the amount of religious 
training which these individuals had had is not known. CONTACTS WITH OTHER SOCIAL AGENCIES

The recovered group had contact with an average of 2.3 different social agencies in the city of Louisville; the unrecovered group with 3.1 different agencies before treatment was begun at the clinic.

THE AVERAGE AGE AT WHICH THE SUBJECTS COMMITTED THEIR FIRST OFFICIAI DELINQUENCY

The recovered group committed their first official delinquency when they were, on the average, thirteen years and eight months old. The arerage age of the unrecovered group was thirteen years and no months. On the average, the unrecovered group started their delinquent careers eight months earlier than the recovered group.

NUMBER OF OFFENSES COMUITTED BY FACH SUBJECT

Individuals

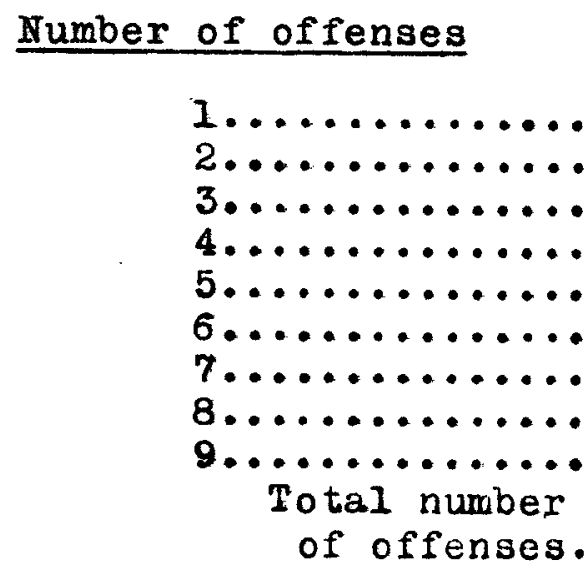

Recovered Unrecovered

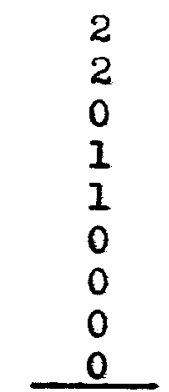

0

2

3

0

3

5

0

0

0

15

65 
The unrecovered group was a more active one as far as committing delinquencies is concerned. They expressed themselves by means of delinquent activities much more frequently than did the recovered group. The unrecovered group committed 65 official delinquencies with an average of 4.6 delinquencies per individual. The recovered individuals committed 15 official delinquencies with an average of 2.5 delinquencies per individual.

of the 65 offenses committed by the unrecovered group, 26 or $40 \%$ were committed before treatment was begun, 10 were committed during the treatment period and 29 took place after treatment had been terminated. Only three of the fourteen committed any delinquencies while they were receiving treatment at the clinic. One of the recovered group was charged with a delinquent act while he was being treated at the clinic but this was dismissed.

Only 10 out of a total of 80 offenses were committed wile these subjects were being treated by a psychiatrist. They were committed by three boys. In other words, seventeen of the twenty did not commit any offenses while they were receiving psychiatric treat- 
ment. These facts make it legitimate to conclude that psychiatric treatment seemed to have a positive correlas tion to the cessation of delinquent activities while this group was under treatment. This may be a lead as to what kind of a treatment program is best for handing cases of this nature, for we see that eleven of the fourteen who committed delinquencies after their contact with the Clinic had been terminated, did not commit any delinquent act during the treatment period. Perhaps these individuals need continuous psychiatric treatment, if we desire to control their delinquent behavior. of course, this is an expensive proposition but if we consider the cost of delinquency and crime to the individual and society, it seems that it would be less expensive to provide adequate psychiatric treatment over a long period of time.

THE NATURE AND NUMBER OF OFFENSES

Three of the six of the recovered group were involved in stealing offenses. They committed $?$ offenses with an average of 2.3 per individual. One stole money and jewelry, another stole an automobile and the third broke into a store and stole articles from it. Twelve of the unrecovered group were responsible for 48 stealing offenses with an arerage of 4.0 offenses per sub- 
THE NATURE AND NUMBER OF OFTENSES

\section{Number of Offenses}

Nature

\section{Recovered}

Unrecovered

Stealing................

Running away.............

Riding in a stolen car....... Possession of stolen goods... Assault and Battery..........

Sex misbehavior.............

Disorderly conduct..........

Ra pe...................

Hopping on street car........

Passing counterfeit money....

Armed robbery

Total

\begin{tabular}{l}
7 \\
4 \\
1 \\
1 \\
1 \\
1 \\
0 \\
0 \\
0 \\
0 \\
0 \\
\hline 15
\end{tabular}

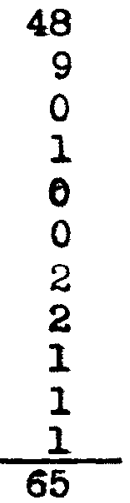

ject. This average is almost twice that of the recovered group's. It is interesting to note that ten of the twelve of the unrecoverea group who were involved in stealing of fenses stole automobiles.

Three of the recovered group and four of the unrecovered group were charged with running away. In terms of percentages, $50 \%$ of the recovered group and $28 \%$ of the unrecovered group were charged with this offense. However, those of the unrecovered group who committed this offense did so about twice as often as the recovered group.

Of the unrecovered group, two were charged with disorderly conduct, one with armed robbery, one with rape, one with hopping on a street car and one with passing counterfeit money. These are certainly overt 
and aggressive forms of delinquencies. As far as the recovered group is concerned, one was charged with assault and battery and one with a minor sex misbehavior.

We can conclude from these results that the unrecovered group was a more active and aggressive one than the recovered group, both in terms of the types of offenses and in the frequency of them. Their behavior was expressed in more overt forms, as far as the delinquent acts are concerned, than the recovered group's.

INSTITUTIONAL AND PROBATIONARY EXPERIENCES

Four of the recovered group were on probation at some time during their delinquent careers. Three were committed to Ormsby Village and one to a federal reformatory. Two of the three who were sent to Ormsby Village had to be returned to that institution because they had committed delinquencies after they had been released. Four of the six had been in sone correctional institution, but they were not in an insitution while they were being treated at the clinic.

Ten of the unrecovered group were placed on probation after their first offense. Six of these ten were later committed to Ormsby Village, one to a federal reformatory and one to jail. Ten of the fourteen 
were committed to Ormsby Village. Eight of them had to be returned there on one or more occasions. Of these ten, two were later committed to the Kentucky House of Reform at Greendale, two to a federal reformatory and one to jail. Eleven of the fourteen had institutional experience. Seven of these eleven had to be sent to institutions where discipline is much more rigid and severe than it is at Ormsby Village. In view of the personality structures of these individuals, the value of sending them to a "stricter" institution seems doubtful.

\section{THE PROBIEMS AS REFERRED TO THE CIINIC}

Problem

Stealing...

Running away $\ldots \ldots \ldots \ldots$........

Uncontrollable..........

Personality problem......

Hyperactive.............

Nervous and irritable....

Bad companions...........

Forgery $\ldots \ldots \ldots \ldots \ldots \ldots$.

Truancy...............

Iying and lack of morals.

School problem. $\underline{\text { Recovered }}$

Unrecovered

A review of this list of problems as they were stated on the referral sheet shows, in part, a fundamental difference between the recovered and unrecovered groups. Eight of the unrecovered group were referred 
as definite personality problems, only one of the recovered group had this as a basis for referral. In addition, the list of problems shows that the behavior which is symptomatic of personality deviation was recognized more frequently in the unrecovered group than in the recovered group. For example, hyperactivity, nervousness, irritability, lying and lack of morals were cited more often as problems of the unrecovered group than the recovered group. If this was apparent to the relatively untrained persons who referred these cases, then it is logical to assume that these differences would appear greater to the trained personnel. This may bive another lead in understanding why six of Group I recovered and fourteen did not.

It is true that these twenty subjects were classified as belonging to Group I. However, this does not mean that the personalities of these individuals were the same. They do have certain characteristics in common but, within any class, there are differences among the specific individuals of that class. The personality deviations of some were greater and more intense in some than in others. It is quite possible that the degree of personality deviation and disturbance was not as great in the recovered group as it was in the un- 
recovered group. If this is true, it is not too farfetched to assume that the members of the recovered group, even though they belonged to Group I, were more amenable to treatment than were the members of the unrecovered group. In other words, it is possible that treatment was successful with the recovered group because the personality deviations of these subjects were not as great or intense as those of the unrecovered group.

AGE AT THE BEGINNING OF THE TRHATMEIVT PERIOD

The recovered group was, on the average, 14 years and 8 months old when treatment was begun. The unrecovered group averaged 13 years and 11 months. Treatment was begun with the unrecovered group when they were, on the average, 9 months younger than the recovered group. However, the unrecovered group began their delinquent careers when they were about 9 months younger than the recovered group.

If we subtract the age at whichthe first official delinquency was committed from the age at the beginning of the treatment period, we see that about 9 months elapsed, on the average, between these two events for both groups. 


\section{IENGTH OF THE TREATUENT PERIOD}

The averase length of the treatment period for the recovered group was 1 year and 3 months; for the unrecovered group the average was 1 jear and 0 months. There was a difference of 3 months in favor of the recovered group.

\section{AVRRAGE NUNBER OF INTERVIETS BETWEEN} PSYCHIATRIST AND SUBJECT

The recovered group had an average of 10.1 interviews per subject; the unrecovered group averaged 10.0 interviews per subject with the psychiatrist. There was no difference between the two groups as far as frequency of contact with the psychiatrist was concerned.

AVERAGE NUMBER OF INTIRVIEWS BETWHEN PARENTS AND SOCIAI WORKERS

The parents of the recovered group averaged 7.0 interviews per case with the social workers and the unrecovered group's parents averaged 6.4 interviews.

TOTAJ TIME SPENT ON TACH CASE

The average time spent on the recovered group was 20.5 interviews per case. The unrecovered group 
averaged 18.7 interviews per case.

These results have important significance because they show that it is not the amount of time which is spent on the case which will determine whether or not treatment will be successful but that other factors are responsible for the cessation of delinquent activities. On the average, the same amount of time was spent with both groups, yet, one recovered and the other did not. Does this mean that treatment was useless for the unrecovered group? Not necessarily, for as we have noted before, eleven of the fourteen did not commit any delinquent act while they were under treatment.

\section{RAPPORT}

Rapport between the psychiatrist and the delinquent was fairly good in five of the six cases of the recovered group. It was not fully established in the other case. Ten of the unrecovered group were in poor rapport with the psychiatrist, no evaluation could be made of the other four cases. This seems to be indicative of the ability which these boys possessed in forming a good relationship with another person. If this was not accomplished under the fairly ideal conditions of the psychiatric situation, it is not hard to under- 
stand how difficult it would be for these boys to accomplish this in everyday life.

REIATIONSHIP BETWEEN THE DELINQUEIT AND HIS PARENTS

If we consider the parents of the recovered group, two of the mothers were over-protective, two were erratic in behavior and one was a warm and affectionate person. Two of the fathers were authoritative and restrictive, two were ineffectual or undependable and two were lax in disciplinary matters.

of the unrecovered group's mothers, five were aggressive or domineering, five rejected the child, three were over-protective, three were restrictive, two were erratic and one was lax in supervision. Of the fathers, four were ineffectual persons, two were restrictive, two were Iax in supervision, one was antagonistic toward the child and one was a dope addict.

Although social pathology existed in both groups, the social situations and relationships of the unrecovered group were far worse than those of the recovered group. This may be an important factor in the social development and behavior of any individual. With the personality make-up that the subjects of this study have, the extra burden of social pathology seems 
to be an important reason why these individuals began and continued their delinquent careers.

\section{THE FOILOW-UP VISIT}

About five years have passed since treatment of the delinquents has been completed at the Clinic. All are no longer of the delinquent-minor age, so that no further delinquencies can be charged against. The tables of this study include the full record of their official delinquencies. In the section on criteria, we said that treatment would be considered successful if the individual is making a satisfactory adjustment in life. That is, if he has been socially productive for the past two years, his adjustment would be considered successful, even though he may have committed a delinquent act after treatment at the CIinic had been terminated. In order to make this evaluation, it was necessary to locate these subjects or find out what they were doing. It was fortunate that, after this period of time, we were able to locate the whereabouts of fifteen of the subjects. We did not see the boys on most occasions but obtained the information from parents or relatives. We, therefore, cannot say much about the personalities of these subjects as they exist to-day. 
Ideally, a follow-up study would be conducted in the Clinic. That is, much more could be learned if the subjects came to the Clinic for a series of psychiatric interviews. Such a procedure would permit a comparison between the former and present stage of the individual's personality development. However, we do know what fifteen of the subjects are doing and can attempt to evaluate their activities.

\section{Successful Adjustment Number of Individuals}

Working.................

U. S. Army $\ldots \ldots \ldots \ldots \ldots \ldots \ldots$

c. c. c...................

Total.......

Unsuccessful Adjustment

In jail or reformatory.....

Not working ...............

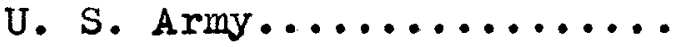

T. B. Sanatorium..........

Total......

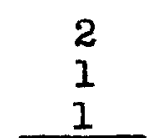

4

Number of Individuals

\begin{tabular}{l}
6 \\
3 \\
1 \\
1 \\
\hline
\end{tabular}

One of the first question that arises is, how many of those who are making a successfulf adjustment to life, at present, comritted any delinquent acts after treatment had been completed at the Clinic and had been rated as unrecovered because of that activity? The answer is that one of the four who are making success- 
ful adjustments at present did commit a delinquent act. As far as those who are not making a successful aajustment at present are concerned, two did not commit any further delinquencies but have to be considered as failures as far as successful treatment is concerned. One has been coming to the Clinic for years. From a research point of view, treatment was valuable. However, from a social and community standpoint, treatment has not been successful. This boy is, perhaps, one of the worst of the entire group. There is no telling when he will "explode" and be a menace to the population. He does not work and is not engaged in any useful activity. It is because of his personality structure and his present adjustment that he must be rated as making an unsuccessful adjustment in life. The other boy is in a tuberculosis sanatorium, the prognosis is poor. It is from the point of view that he is socially unproductive that he is rated as making an unsuccessful adjustment in life.

It would be, perhaps, of value to discuss at greater length, the adjustments which have been made by the subjects studied, for they cannot be accepted withqualification. 
Two are working, one as a shoe salesman and the other as a helper on an ice wagon. It may be thought that working on an ice wagon is not a very satisfactory adjustment to make in life. When we consider that this boy has an I.Q. of 84 , we can see that this position is in keeping with his abilities. One is in the army. So far, there have been no reports of misbehavior. This is also true of the boy who has been in the $C . C . C$. for the past two years.

of those who are making an unsuccessful adjustment in Iife, three are in a federal reformatory, two are in the Kentucky House of Reform at Greendale and one is in the county jail. Three are not working nor have they attempted to find any position. One is in the army but he is a constant disciplinary problem, being A. W. O. I. frequently. one is in a tuberculosis sanatorium

There seems to be a close connection between the two criterion which were uitilized. The ones who no longer committed any delinquencies after treatment had been completed, tended to be the ones who are making a 
successful adjustment to life, at present. Those who continued their delinquent careers are those who are not making a successful adjustment, at present, whether they are in a correctional institution or not. 
CHAPTER 5

THEORETICAI DISCUSSION 
CHAPTER 5

THEORETICAI DISCUSSION

Before any conclusions are drawn, it seems best that there should be some theoretical discussion of the ideas which we have developed. This material is based upon the data which has been collected.

We shall briefly consider the concept of delinquency. Delinquency is, in a sense, an unfortunate term. Because of its use and popularity, emphasis has been given to the term or the offense rather than to the delinquent indiviaual. If we are to make progress in this field, we shall have to concentrate upon the individual who has committed a delinquent act rather than upon the delinquency, as such. The physician does not treat small-pox, he treats a patient with small-pox. The psychiatrist does not treat a neurosis, he treats a patient who is neurotic. The same line of reasoning should be applied to the field of juvenile delinquency. It is not the delinquency which should be treated, it is the individual who has committed a delinquent act who needs the treatment. Our reformatories and prisons were constructed because the delinquency and the crime were the centers of interest. It was to prevent delinquency and crime that the penal in- 
stitutions were built. Rather than speak of delinquency, it would, perhaps, be better if we spoke of the individual who has committed a delinquent act.

Too much emphasis has been placed on the offense as an offense. We must consider what each delinquent act means to the individual who commits it. The same delinquent of fense does not have the same meaning for each boy. For example, in our group, stealing was an act of rebellion for one boy and was a source of adventure and excitement in an otherwise aull life for another.

Delinquent ucts are overt and active means by which an indiviaual expresses himself. Most of the time; the delinquent act is condemned. The aim of most treatment progrsms is to prevent delinquency. However, there is another viewpoint which is worthy of consideration. Any boy who has committed a delinquent act has expressed himself in overt terms. He has not withdrawn and kept everything within himself. We know that, at times, the delinquent act is symptomatic of underlying needs and desires. From a therapeutic standpoint, the chances of successful treatment are much higher with the person who does express himself through open and active channels than with those who interiorize their 
feelings and desires and who are unapproachable because they are not in contact with reality.

We have mentioned that only three of the twenty subjects of this study committed any delinquent acts while they were under treatment and that seventeen did not. Certainly, treatment must be considered successful during this period. It will be recalled that the twenty of thi group were classified as belonging to Healy's Group I. This group is considered the most hopeless of the three groups, as far as treatment is concerned by Healy. Healy reported that only one of his Group I subjects ceased committing delinquencies at the end of the treatment period. Six of our group were treated successfully. Why the difference? Although the numbers are small, this is a valid and important question. So far as we know, there has been no subsequent studies reported in the literature on delinquents of the Healy Group I type, who have received intensive pgychiatric treatment, to aetermine the factors which differentiated the recovered from the unrecovered indiviauals of this group. Healy could not make this analysis because there was only one who recovered. It was possible for us to make this attempt because there were six individuals who recovered. Perhaps, part of the answer to the question is that more 
is known ahout the psychopathic personality to-day by all therapists and, as a result, treatment has become more effective.

We have had several discussions with the Medm ical Director of the Mental Hygiene Clinic on the question of the most effective and proper treatment of the psychopathic personality. Our conclusions were based, mainly, on the fact that the results of this study showed that most of the delinquent activities ceased while this group was receiving treatment at the Clinic.

One of the chief complaints of the lay person is that the psychopath has little or no morals, guilt feelings or shame. To be sure, all generalizations and classifications need to be considered cautiously. These psychopaths, aIthough they may not show it, are often filled with heavily blanketed guilt feelings. In fact, that is one reason why it is so difficult to treat them, but, by the same token, treatment is possible. It is quite possible that they have so much guilt feeling that, to protect themselves, they build a wall which shuts out expressions of feelings by them and does not permit them to be emotionally affected by external stimuli. That wall is stronger in some indivi- 
duals than it is in others. It, then, becomes a question of finding the most effective means for breaking down that wall and reaching the person behind it.

It is for this reason that we are questioning the effectiveness of institutionalization or physical punishment in the treatment of the psychopath. Often, the psychopath will go out of $h$ is way to be given a terrific physical beating. Why? The psychopath feels that if he receives or experiences physical pain, he has been punished for his misdeeds. This is true, not only of the psychopath, but of most of us, as well. Physical punishment is an easier way to expiate guilt than on a higher abstract level and the psychopath seems more content to suffer this way. The major difference between the normal individual and the psychopath is that the latter feels more free to go out and commit another of fense and usually does.

In one sense, psychiatric or "mental" treatment is a more severe form of punishment, at least for the psychopath, than is incarceration or a whipping. How many of us would rather have been whipped than "talked to" by our parents? It is or may be that much more intense for the psychopath. It must be extremely painful for the psychopath to find a person who will accept 
him and treat him with kindness and respect, in spite of the fact that he may have committed some of the worst and "meanest" social offenses, perhaps against the psychiatrist, himself. We do not mean that we would advise psychiatric treatment because it would be the most severe form of punishment. We believe that this effect is one of the most important features of the treatment situation. For instance, a psychopathic patient hit a psychiatrist, who was treating her, over the head while the doctor's back was turned. The psychiatrist picked himself up, said, "I'm sorry." and walked away. He instructed the nurses and attendants to say nothing about the event nor to physically punish the patient. The patient broke down and cried for a very long time. It was the first time anyone had seen the patient express any feeling and this was the turning point in the treatment situation. So with other psychopathic personalities, psychiatric treatment may not be effective in all cases, but it is the only method which can be effective. physical restraint or institutionalization, without psychiatric treatment, merely prolongs the psychopathic conaition, for the use of these procedures mean, to the osychopath, that he has been punished for his offenses and is, now, free to 
commit some more.

We have all seen what happens to a spring that is wound too tightly. A certain degree of tension is reached, then the spring snaps and there is a whir of movement as the spring unwinds. The psychopath is like that overwound spring. He, too, becomes wound too tiohtly and snaps. We call his behavior impulsive. In relation to the group studied, it seems that while these subjects were receiving treatment at the clinic, their degree of tension was kept below "snapping point". They were able to get rid of much energy and tension at the CIinic, therefore, it was not necessary for them to do so on the outsice.

As a result of our finaings, we would recommena continuous and intensive psychiatric treatment for in dividuals of Healy's Group I.

To return to some of the other data, we have found that six of the group recovered and fourteen did not. We have suggested that the higher percentage of recovery, in this study than in Healy's, has been due, in part, to improvement in technique and in a better understandine of the personalities of these subjects. 
However, there are other facts which we have found. First of all, the social situations of the unrecovered group were wuch worse than those of the recovered eroup. A few woras about social situations and environment would not be out of order at this time. We shall not raise the question of heredity and environment, but it seems to us that one of the most important and funaamental principles has been ignored by most investiEators. It is not the environmental conaitions or social situations, as they exist in a physical sense, that affect the behavior of an individual. It is the meaning that the environmental setting has for the individual that will determine its effect upon him. A poor home, in itself will not produce a delinquent child, but if the chila feels that "Because this is a poor home, I cannot have what I want.", then it becones more understandable why the child uses delinquent means to obtain what he wants. It is not the poor home tiat was responsible for the delinquent activities but the evaluation that was made of that home by the child who was living in it that produced the delinquent behavior. Therefore, when we say the social situations of the unrecoverea group were worse than those of the recovered group's, we mean 
that the effect of the social pathology was greater upon the unrecovered oroup than upon the recovered Łroup.

This section has been, mainly, an attempt to formulate a plan which would seem to be adequate for the treatment of delinquents who belont to Healy's Group I. We believe that the treatment program which is recommended would, in the long run, be less expensive to society than the present cost of delinquency anà crime. 
CHAPTER 6

CONCIUS IONS 
CHAPTER 6

CONCLUSIONS

An analysis of the sample and the methodology which was used in this study makes the following conclusions appear to be valia:

1. Treatment of delinquents who belons to Group I can be successful insofar as cessation of delinquent activities are concerned. The results of this study show that only three out of the twenty cormitted any delinquencies while they were being treated at the Louisville Mental Hygiene Clinic.

2. It is possible that there is more hope for treatment of the subjects who fall into Group I than has originally been thought. The results show that six of our group have not been delinquent since treatment has been completea.

3. Within any classification unit there is a range of variability. This seems to be true of the subjects of Group I as well. Some have more severe mental conflicts than others, the social situations of some are better than others. It was true that the social pathology of the unrecovered froup was much worse than that of the recovered group. This may be a partial explanation of why some responad to treatment and others did not. 
4. The unrecovered group was a much more active and aggressive group than the recovered, insofar as the number and nature of the offenses which were committed are concerned. They committed 65 offenses, whereas, the recovered sroup committed 15 offenses.

5. It is felt that the overtness of the delinquent act may itseif have some therapeutic imortance. 6. A plan for the treatment of delinquents who fall into Group I has been formulated. This plan calls for more intensive and continuous psychiatric treatment and is based upon the fact that delinquent activities ceased in seventeen of the twenty cases during the treatment period.

7. A follow-up study of the subjects shows that there is a positive correlation between cessation of aelinquent activities and a successful life adjustment after the delinquent-minor age has been passea. 
APPENDIX A 


\section{CASE HISTORIES}

1. H. S. age Il-0, I. Q. צ8, only chila, Catholic. Physical condition good but patient was nervous. Psychiatric Findings: Developing psychopath. Social Findings: Broken home. Mother cver-protective. present Status: Not located. Age 18-2.

$$
\text { 2. I. G. age 12-2, I. Q. 109, olaest of four }
$$
siblings, Baptist, physical condition good. Psychiatric Findings: Patient scornful, braseer, "cocky," fundamentally frustrated and insecure. Delinquency was rebellion against mother's domination. Patient striving for recognition and acceptance. Social Findings: Hother domineering, a social climber. Poor marital relations. Sibling rivalry with halfbrother. Rejection of patient by mother. Iwother aid not co-operate with the clinic. Present Status: Patient is in the U. S. Army. Age 22-6. 3. E. S. age $12-5, I, Q \cdot 94,3$ rả of five siblings, Baptist, physical conaition good. Psychiatric pinainos: patient surly, suspicious, paranoid trend. Wuch resentment and rebellion with projection. Immature emotional make-up. Definite psychopathic case. 
Social Findings: Extremely bad social pathology. Tension and conflict in the home. Rigid father and colä mother.

Present Status: Patient in the C. C. C. Age 18-3. 4. I. G. age 1I-7, I. Q. 96, only chilo, physical condition good though patient was nervous. Psychiatric Findings: Definitely sexual psychopath. Unconcious rebeliion against wother, patient hyperactive and insecure. Social Finaings: Broken home, rigid, neurotic mother. Present status: Patient in jail because of rape. Age $19-5$.

$$
\text { b. A. V. age 12-6, I. Q. 114, 2nd of } 3 \text { siblings, }
$$

Baptist, physical condition good.

Psychiatric Finaings: Extremely impulsive. Unstable. Miany fears. Suave and smoothe.

Social Findings: Patient illegitimate. A "black sheep". Nother a religious fanatic, unstable and paranoid. Father was unstable.

Present status: In federal reformatory. Age 17-0. 
6. F. K. age 12-7, I.Q. 108, youngest of 4 siblings, Baptist. Head injury. Patient unconscious for some time.

Psychiatric Findings: Confirmed psychopath. Swindler type. Couldn't be reached. Impervious to emotional appeal. Indifferent.

Social Findings: Marital difficulties. Mother an ardent church member, father a gambler. Presesnt status: Not located. Age 19-6.

7. H. T. age 12-9, I. Q. 137, oldest of 3 siblings, Protestant, good physical condition. Psychiatric Findings: Physical inferiority feelings and intense feelings of intellectual superiority. Too bright for his cultural surroundings. Tries to outwit everyone.

Social Findings: Mother a perfectionist. Rigid. Present Status: Moved. Age 20-0.

$$
\text { 8. J. I. age 13-0, I. Q. } 89 \text {, youngest of } 5
$$

siblings, Episcopal Chouch, had head injury and was unconscious.

Psychiatric Findings: Frustrated, awkward, ineffectual. Frank homosexual. Casual and aloof. Lack of drive. 
81

Social Findings: Domineering mother, father ineffectual. Mother aggressive.

Present Status: In army. A. W. O. I. frequently.

9. T. N. A. age 13-3, I. Q. 84 , only child, Protestant. Head injury and unconscious. Psychiatric Pindings: Always un-moral. No sense of right or wrong. Destructive. Unstable. Has temper tantrums. Glib promises maue by patient. Restless. Social Finaings: Father extremely severe. Hother high-strung. Present Status: Patient is working on an ice wagon. Age 24-7.

10. R. A. age 13-3, I. Q. 90, only child. Instrument birth.

Psychiatric Finaings: Inate Instability. Always nervous. Deep-seated Fears. Neurotic tendencies. Imotionally unstable.

Social Finaings: Broken home. Mother rejected patient. Unstable home life.

Present Status: Not located. Age 18-8.

11. I. D. age 14-4, I. Q. 98, 3rd of 4 siblings, Catholic. Hyperactive.

Psychiatric Finaings: Weak, no restraint. Very unstable. 
Social Findings: Bad social pathology. poor family relationships. Rejection. Present Status: Patient in Waverly Fills T. B. Sanatorium. Age 22-8.

12. M. D. age 14-7, I. Q. 93, only child, Baptist. Adopted.

Psychiatric Pindings: Immature. Extremely dependent upon mother. Anal and oral homosexual. Much fantasy, withorawal and rationalization.

Social Findings: Masculine, domineering, restrictive, unstable mother.

present status: Not working. Age 17-0.

13. C. P. age 14-11, I. Q. 104, 3rd of $4 \mathrm{sib-}$

lings. May have been organic brain aisturbance present. Possible frontal lobe atrophy.

Psychiatric Findings: Homosexual. Strong mother

attachment. Developing psychopath?

Social Findings: Fairly good.

Present Status: Not located but last report was that patient was divorcing his wife. Age 20-11.

14. C. I. age 15-3, I. Q. 107, only child, Protestant. Good physical condition.

Paychiatric Findings: Inadequate father, rejecting mother, which resulted in intense feelings of insecurity. Paychopathic personality. Neurotic traits. Deceptive. 
Social Pindings: Supervision inadequate. Parents indifferent.

Present Status: In Greendale. Age 17-4.

15. H. F. age 15-8, I. Q. 109, 3rd of 4 siblings. physical condition good. Psychiatric Findings: Inaccessible, unresponsive. Insensitive to emotional appeal. Psychopathic personality. Social Findings: Extremely bad social pathology. lother dead. Father a dope adict. Present Status: In Greendale. Age 19-3.

16. J. W. M. age 15-10, I. Q. 97, foster child, Christian Church. Good physical conaition. psychiatric pinaings: Patient extremely unstable. Acute anxiety state. Numerous neurotic traits. Conflicted. Later a smooth manner. Social Findings: Foster parents old. Tyrants. Demanding and restrictive. Present status: In federal reformatory. Age 20-0. 17. J. M. age 15-11, I. Q. 101, oldest of 3 siblings, Catholic. Instrumental birth, head injury later in Iife. 
Psychiatric Findings: Impulsive. Psychopathic personality.

Social Findings: Fairly good home.

Present status: Patient has been working for two years in a shoe store. Age 21-4.

18. I. E. age $16-4$, I. Q. 109, only child, Baptist. Good physical condition.

Psychiatric Findings: Manic-flights. Emotionally unstable, impulsive. Psychopathic personality.

Social Findings: Father dead. Hother unstable, erratic, neurotic.

Present Status: In reformatory. Age 19-7.

19. T. R. age 16-5, I. Q. 119, oldest of 2 sibIings, Baptist. Good physical condition.

Psychiatric Pinaings: Psychopathic personality. Emotional flights. Manic condition. Swings in energy output. Fantasy.

Social Findings: Broken home. Nother erratic. Present Status: Not working. Not aelinquent but potentially aangerous. Age 22-4.

20. A. W. age 16-II, I. Q. 92 , 2nd of 5 siblings, Baptist. Had head injury. 
Psychiatric Findings: Day-areamer, brooder. Fmotionally inadequate. High temper.

Social Findings: Unstable home. Father alcoholic. Nother dead. Step-mother inadequate.

Present Status: Not located. A\&e 20-1. 
APPENDIX B 
THE LOUISVIILE MISTAL HYG IENE CIINIC

The Louisville Mental Hygiene Clinic is located at 610 s. Floyd Street, Louisville, Kentucky. Its staff consists of two full-time paychiatrists, two parttime psychiatrists, three psycriatric social workers and one student from the University of Iouisville, Graduate Division of Social Aaministration who receives psychiatric social case work training.

The clinic does not serve only the Juvenile court. In fact, Juvenile court cases are but a suall percentage of the total case load. Adults as well as children are treated. Frank neuroses or psychoses are usually not accepted by the clinic. These are most frequently treated by the psychiatric staff of the Louisville General Hospital or are referrea to a state institution.

As far as chilaren are concerned, the types of cases involve jersonality or behavior dificulties. The goal of the clinic's work is to prevent the develogment of psychoses or neuroses by resolving the problem before the person reaches a psychotic or neurotic stace. In this sense, the work is preventative. 
If we use a child as an example, the procedure at the clinic is somewhat as follows:

There is a referral or intake interview with the mother (or person most closely related or interested in the child) in order to get some unaerstanding of the problem, to obtain some information as to the background of the problem and to find out what has been àone by the parents in meeting the problem. The intake worker attempts to find out whether or not the parent is coming to the Clinic because she was forced to do so by the referring agency. The worker attempts to find sowe evidence that the parent will co-operate in the treatment situation. The major reason for incluaing the parent in the treatment program is the fact that many of the difficulties of the child have their roots in the relationship that exists between the parent and child. Often the behavior problems are reactions of children against a restrictive or over-protective parent. As long as the child is in the home, little change can be expected if only the chila is treated for the same forces which brought about the problem would continue. The parent, therefore, must be included in the treatment situation if permanent changes are to be made. The parent is the one who decides whether or not she would 
like to come to the clinic. She has the final say in this matter for little woula be accomplished without her co-operation. The intake interview serves as a clearing ground. The parent is told what the clinic has to offer and what is expected of her.

once a case is accepted, appointments are made on a weekly basis. Both parent and child are seen for one hour. Usually, the psychiatrist sees the child and the social worker, the parent. There is no time limit set upon the length of the treatment period but this factor is not entirely uncontrolled. There is a close workin relationship between the psychiatrist and the social worker. Informal as well as formal conferences are held to determine the treatment prosram and to evaluate the work that has been done.

We shall not discuss, here, the therapeutic or case work processes that are employed at the clinic. suffice it to say tinat the staff works out a joint plan and attempts to utilize the community resources which are available. 
APPENDIX C 


\section{SCHEDULS}

Prior to Treatment

1. Name 2. Address

3. Birthdate 4. Age (present)

5. I. Q. 6. Socio-economic Status

7. Birthplace 8. Home conditions

a) of delinquent

b) of father

c) of mother

9. Religion

10. Ne ighborhood

11. Family Relations

12. Delinquency or Mental Abnormalities in the Family

13. Fducation

14. Siblings (age and sex)

15. Position in the Family

16. Age of First Delinquency

17. Use of Leisure Time

18. Physical condition 
Treatment period

1. Length of Treatment period

2. Number of Interviews with Delinquent

3. Number of Interviews with Parent

4. Number of Conferences

5. Total Time

6. Psychiatric Findings

7. Hedical Findings

8. Social Findings

9. Nature of the Treatment

10. Delinquent's Behavior auring Treatment

11. Changes in Delinquent's Personality and Attitudes

12. Changes in Family Attitudes and Relationships 
Follow-up 1942

1. Address 2. Present AEe

3. Occupation 4. Marital status

5. Socio-economic Status

6. Home Conaitions

7. Neighborhood 8. Ramily Relations

9. Interview

10. Evaluation of Treatment 
COURT RECORD

Date

Charge

Disposition 
BIBLIOGRAPHY 


\section{BIBLIOGRAPHY}

\section{BOOKS}

Adler, A. The practice and Theory of Individual Psychology: New York: Harcourt, Brace and Co., 1932.

Aichorn, A. Wayward Youth. New York: The Viking press, 1935 .

Alexander, F. \& Healy, W. Roots of Crime. New York, London: A. A. Knopf, 1935.

Bird, C. Social Psychology. New York \& Iondon: D. Appleton-Century Co., 1940.

Burt, C. I. The Young Delinquent. New York: D. Appleton and Co., 1930.

Freud, S. The Basic Writings of Sigmund Freud. Translated by Dr. A. A. Brill. Ilew York: The Yodern Library, 1938.

Glueck, S. \& Glueck, E. T. Five Hundred Criminal Careers. New York: Knopf, 1930.

- One Thousand Jurenile Delinquents. Cambridge: Harvard University Press, 1934 .

- Preventing crime, A Symposium. New York: licGraw-HiII, 1936 .

- Later Criminal Careers. New York: The comnonwealth Fund, 1937 .

- Juvenile Delinquents Grown-Up. New York: The Commonwealth Fund, Oxford University Press, 1940 .

Guthrie, E. The Psychology of Human Conflict. New York: Harper \& Brothers Publishers, 1938 .

Healy, whe Individual Delinquent. Boston: Iittle, Brown and Co., 1915.

- Reconstructing Behavior in Youth. New York \& London: A. A. Knopf, 1929. 
Healy, W. \& Bronner, A. New Iight on Delinquency and Its Treatment. Hew Haven: Yale Jniversity Press, 1936.

Hirsch, N. D. H. Dynamic Causes of Crime. Cambridge: Mass. Sci. Art. Publishers, 1937.

Horney, $K$. The Neurotic Personality of our Time. New York: W. W. Norton \& Co., Inc., 1937.

Lewin, K. A Dynamic Theory of Personality. Translated by D. Adams \& K. F. Zener. New York \& London: MCGraw-Hill Book Co., Inc., 1935.

Reckless, W. C. Juvenile Delinquency. New York \& London: TcGraw-HiII Book Co. Inc., 1932.

Shaw, C. R., Delinquency Areas. Chicago: University of Chicago Press, 1929.

- The Jack-Roller. Chicago: The University of Chicago Press, 1930.

- The Natural History of a Juvenile Delinquent. Chicago: The University of Chicago Press, 1931.

The White House Conference on Child Health and Protection. Section IV. The Handicapped. New York: The Century Co., $193 \overline{2}$

\section{ARTICIES}

Ackerly, S. Rebellion and Its Relation to Delinquency. and Neuroses in Sixty Adolescents. Arner. J. of Orthopsychiatry. Vol. III. No. 2, April, 1933.

Armstrong, C. P. Psychoneurotic Reactions of Juvenile Boys and Girls. J. of Abn. and Soc. Psy., Vol. 32, 1937.

Carroll's Revised Statutes. Definition of a Delinquent Chila. Section 33lei, Ohio: Balawin, 1936. 
Dressler, D. Case Work in Parole. The Family. Vol. XXII. No. 1, March, 1941.

- Case Work in an Authoritarian Agency. The Family. VoI. XXII. No. 8, December, 194I.

Durea, M. A. Personality Characteristics of Juvenile offenaers in Relation to Degree of Delinquency. J. of Gen. Psy. Vol. 52, 1938 .

Drewry, P. Treatinent Possible in an Institution for Delinquents. Amer. J. of Orthopsy. VoI. IX, 1939.

Flexner, B. \& Oppenheimer, R. The Legal Aspect of the Juvenile Court. U. S. Children's Bureau Pub., No. 99, 1922 .

Grossinan, G. Role of the Institution in the Treatment of Delinquents. Amer. J. of Orthopsy. Vol. VIII, January I9 38 .

King, A. Changing the Delinquent Attitude. Pub. by the School of Applied Sciences of Western Reserve University, Cleveland, Ohio. 1927.

Iay, M. The Juvenile Delinquent. The News-Letter of A. A. P.S.W. VoI.XI, No. I, July, 1941.

Metfessel, M. \& Lovell, C. Recent Litexature on Inaividual Correlates of Crime. Psy. Bull., Vol. 39, No. 3, March, 1942.

Rosenthal, P. Group Studies of Pre-Adolescent Delinguent Boys. Amer.J. of Orthopsy. Vol. XII, No. 1, January, 1942.

SIawson, J. The Use of an Authoritative Approach in Social Case Work in the Fiela of Delinquency. Amer. J. of Orthopsy. Vol. VIII, I938.

Speer, G. Wishes, Fears, Interests and Identifications of Delinquent Boys. Child Development. Vol. 8, 1937.

U.S.Chilaren's Bureau. Juvenile Court Standaras. Pub. 12I, 1934 .

- Juvenile Court Statistics. Pub. 159, 1933. 